
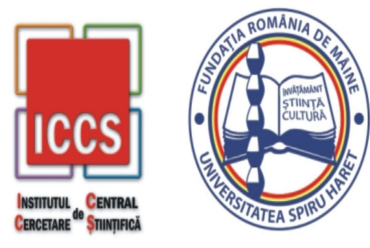

Issue 2/2019

\title{
FIRM VALUATION CONCEPT AND DISCOUNTED CASH FLOW METHOD: A COMPARISON OF STOCK MARKETS
}

\author{
Esref Savaş BAŞCI ${ }^{1}$ \\ ${ }^{1}$ Hitit University, Faculty of Economics and Administrative Sciences, \\ Banking and Finance Department, Kuzey Kampüsü, Çevre Yolu Blv., \\ 19030 Çorum Merkez/Çorum, Turkey, Telephone: +903642191919, \\ Email: esavasbasci@hitit.edu.tr
}

How to cite: BAŞCI, E. S. (2019). "Firm Valuation Concept and Discounted Cash Flow Method: A Comparison of Stock Markets.” Annals of Spiru Haret University. Economic Series, 19(2), 51-59, doi: https://doi.org/10.26458/1922

\begin{abstract}
Company (or firm) valuation - an evaluation process of a company to appreciate the value of a company's right in this company or business. There are two objective and subjective aspects of value. The subjective value is the value determined by individuals and desires. For example, it is a subjective decision that the investor assesses the competitor over the normal to be monopoly in the market. The objective value is the value determined by the cost and benefits of the goods and services.

Although there are many performance measures that measure company success, none is as comprehensive as value. There is a strong and linear relationship between a company's market value and its discounted cash flows. Because earnings are used to generate the income statement, they cannot be used to measure cash flows.

Firm valuation means seeking the goal of the firm which is listing it on the Stock Exchange. Real value of the firm can be calculate with different methodologies. These methods are related to future expectations or background of the firm's financial data. Discounted Cash Flow (DCF) Method is one of the firm valuation methods used all around the world and it is accepted by the experts.
\end{abstract}




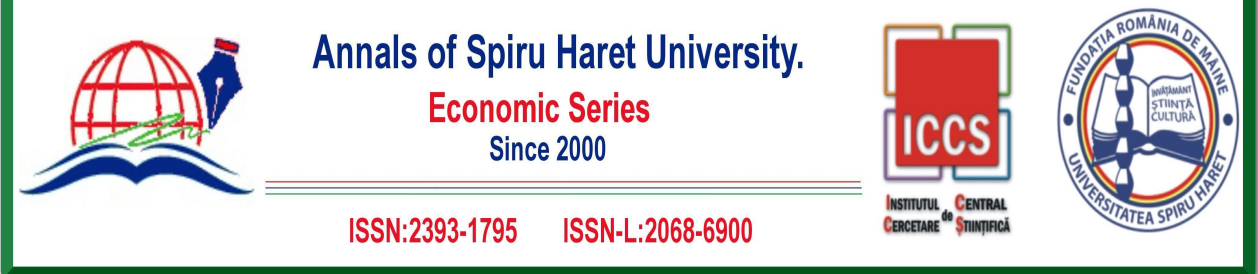

Issue 2/2019

Market value is also used for comparison and performance measurement purposes. Valuation of a company's future expectations, current status, mergers or acquisitions is extremely important. Even the firm value can be used to compare the capital markets of countries. In our study, capital markets and total market values of selected countries are compared. The increase in the share price increases the market value of the company. Therefore, the aim of the firms should be to increase the shareholder value or to take decisions to increase the stock price.

Keywords: firm valuation; discounted cash flow; comparison of stock markets.

JEL Classification: G10, G15, G40, C20

\section{Introduction}

The concept of value represents the magnitude of the discounted cash flows over time, representing the future net profit. The idea of valuation aims to determine the price reflecting the real value of the asset.

Traditionally, market price, cost and income are used approaches to asset valuation. The market approach assumes that the market price of the market will be balanced by investigating the price of comparable assets in the market. The cost approach takes into account the cost of the asset to be re-produced or renewed considering the future profitability of the asset. The income approach is obtained by reducing the profitability of the cash flows of the asset to its present value. All valuation methods aim to estimate the value of assets as accurately as possible. However, the ineffectiveness of the markets leads to an inability to be accurately priced in their assets.

According to the efficient market hypothesis, markets are able to correct themselves by acquiring new information about assets. Therefore, although volatility in the market makes it difficult to make accurate predictions, the expected cash flows in terms of growth rate or profit margin can be demonstrated by using new information about the asset. In the effective markets, market prices form the basis of the estimation of the value of the asset, while valuation methods aim to verify the value.

Company (or firm) valuation is an evaluation process of a company to appreciate the value of a company's right in this company or business. There are 


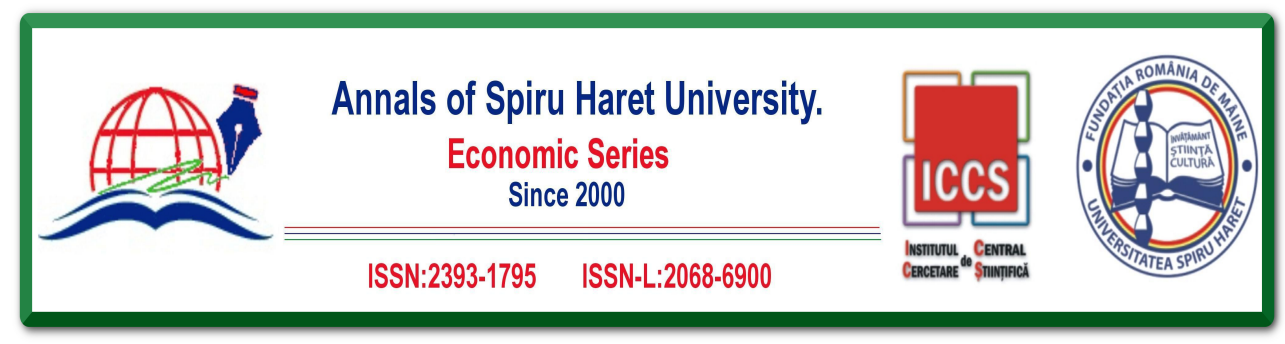

Issue 2/2019

two objective and subjective aspects of value. The subjective value is the value determined by individuals and desires. For example, it is a subjective decision that the investor assesses the competitor over the normal to be monopoly in the market. The objective value is the value determined by the cost and benefits of the goods and services.

Although there are many performance measures that measure company success, none is as comprehensive as value. There is a strong and linear relationship between a company's market value and its discounted cash flows. Because earnings are used to generate the income statement, they cannot be used to measure cash flows.

In capital investments, investments that are returned in a few years are preferred instead of long-term investments. In such cases, the valuation and valuation expert will be more important.

For many reasons we may need to know the value of the company. Firms need realization of their value by purchasing, mergers, corporate public offering, privatization activities and internal strategic management decisions.

\section{Theoretical Background of Firm Valuation}

Firm valuation means seeking the goal of the firm which is listing it on the Stock Exchange. Real value of the firm can be calculate with different methodologies. These methods are related to future expectations or background of the firm's financial data. Discounted Cash Flow (DCF) Method is one of the firm valuation methods used all around the world and it is accepted by the experts.

DCF's method was demonstrated by Irving Fisher in 1930. According to this method, company assets express a value as long as they can generate cash. Therefore, future cash flows of company's value could be determined by estimating. Any risk for future cash flows in case of insignificance, the early realization of cash flows by rational investors, will be preferred to be evaluated and interest income can be obtained.

Postponing cash flows to a future date means the time value of money (opportunity cost). Considering that the cost of the opportunity can be obtained, the future cash flows, the best available to the investor from the opportunity to return to the current time can occur [Guj, 2006]. The DCF method is based on two basic principles [Pomoni, 2010]:

- Each asset, cash flow, growth and risk has an intrinsic value. 


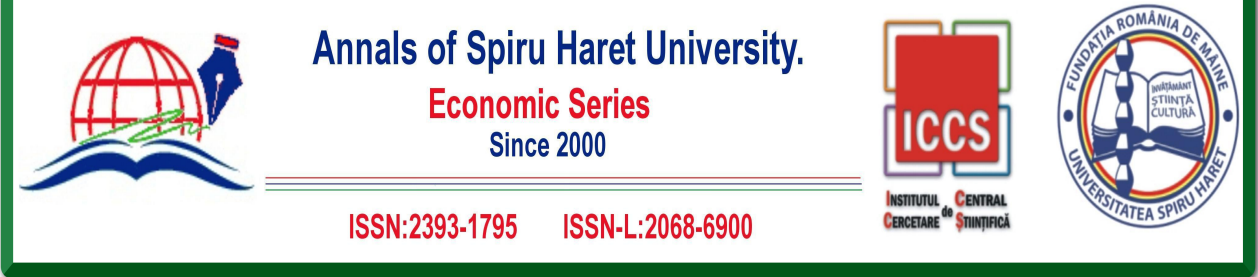

Issue 2/2019

- If the market is inactive and assets are not priced perfectly genius, this situation with the acquisition of new information about the asset may be corrected.

DCF methods present the value of the asset, the expected cash flows of the asset is based on the assumption that the value is equal. The method involves both entities and firms [Pomoni, 2010]. Net present value (NPV) stands out as the most used DCF method. In question value that shareholders will make similar assets with the same systematic risk the expected cash flows of the investment [Broyles, 2003].

In the DCF method, the value of the firm (asset) is mainly based on two different methods. These methods are free cash flow to the firm and free cash flow to equity methods. In the current trends approach, only equity holders cash flows are expected to be provided. Free cash to the company in calculating the current value of cash flows while the discount rate used is WACC, free cash flows to equity. The discount rate used in its approach is the cost of equity. This is basically the reason why these two methods are different [Aydın, 2012]. While the source uses cash flow and equity profitability, the firm cost of capital as a discount rate free cash flow and operating income growth is used. In both methods, in the calculation of expected cash flows is used [Pomoni, 2010].

Net cash flows are discounted to their equity present value is reached. The cash flow to the firm is pre-debt the principal and interest payments of the lenders need to be deducted. However, this method belongs to the lenders in cash flow method payments must be deducted from cash flows [Bal, 2011]. Main concept of the discounted cash flow via using free cash flow to firm can be calculate as follow:

$$
\text { Firm Value }=\sum_{t=1}^{n} \frac{\text { FCFF }_{t}}{\left(1+k_{\text {WACChg }}\right)^{t}}+\ldots+\frac{\text { FCFF }_{n+1}}{\left(k_{\text {WACCst }}-g_{n}\right)} \times \frac{1}{\left(1+k_{\text {WACChg }}\right)^{n}}
$$

The opportunity cost of firm capital to understand the DCF method is a basic requirement. Companies to provide for their equity and equity capital it is both groups have a percentage of return on the risk. Lenders, as well as fixed payments, say payments if not, they may request liquidation or bankruptcy of the company.

On the other hand, the shareholders receive the remaining cash flows. As a result, interest is paid to lenders due to less risk of debt; lower than the required 


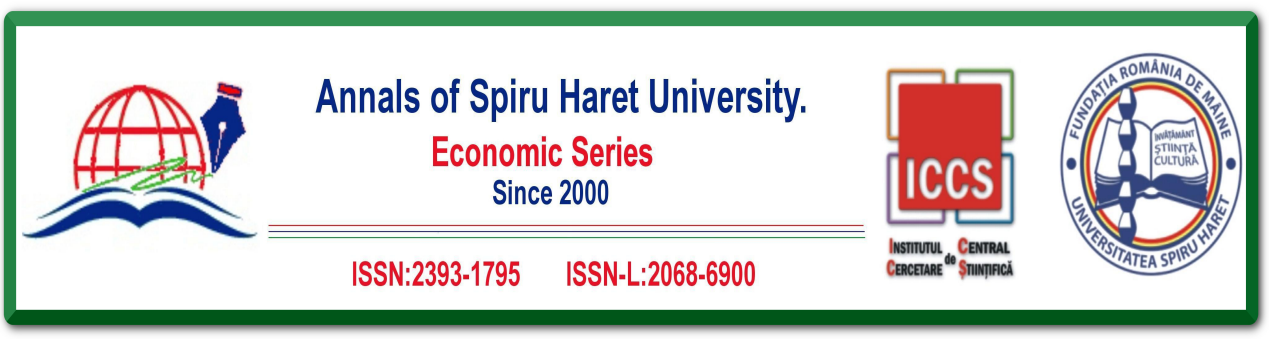

Issue 2/2019

rate of return of capital. Discounting cash flows from WACC is an expression of this situation [Copeland et al., 2003; O'Brien, 2003]. And it is calculated as follow:

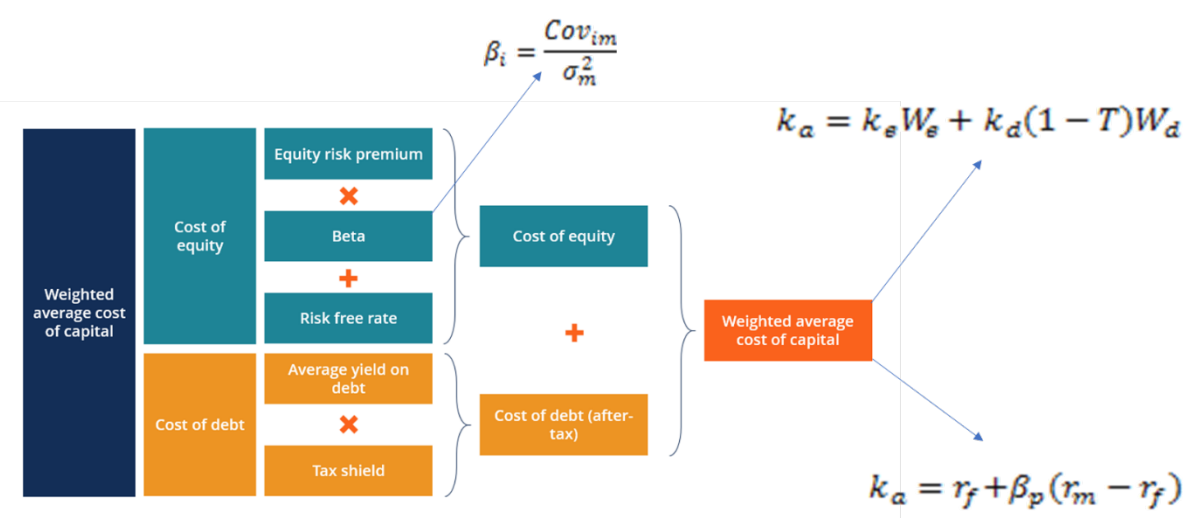

Fig. 1. Weighted Average Cost of Capital Methodology
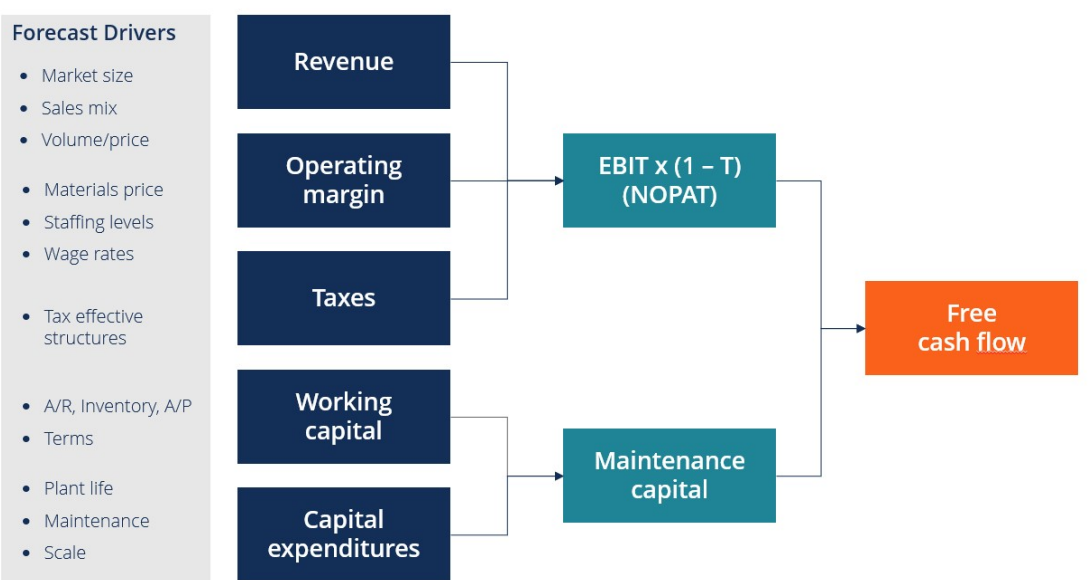

Fig. 2. Free Cash Flow to Firm as Discounted Cash Flow Methodology Source: https://www.investopedia.com 


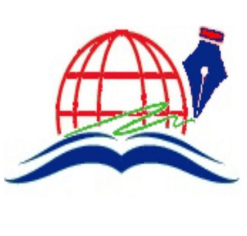

Annals of Spiru Haret University.

Economic Series

Since 2000
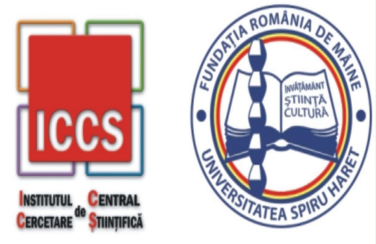

Issue 2/2019

In Figure 1, all steps demonstrate the firm's cost of capital. Beta $(\beta)$ is the systematic risk and it can be calculated by dividing the covariance of the firm and market to variance of the market. $\mathrm{K}_{\mathrm{a}}$ also means that the cost of capital is as a leveraged loan.

Free cash flows are discounted by weighted average cost of capital. The reason for using the weighted average cost of capital is that cash flows are cash flows to all resource owners. Free cash flows method is discounted by weighted average cost of the company and the present value of the debts is deducted and the value of the company should be determined. We can calculate free cash flows to the company as shown in figure 2 .

The free cash flow model is used in companies whose financial leverage is high and debt ratios vary from year to year. This method gives more information about the value of the firm according to different financing and investment strategies.

\section{Comparison of the Exchange Markets}

Comparing the financial tables and firm value of the Microsoft company operating on the NASDAQ stock exchange, it is better understood why the firm's purpose is not profit maximization. If the owners of Microsoft Co. identified the profit objective as their target, they would have to develop new strategies to increase the most recent profit.

Table 1. Annual Income Statement, Balance Sheet and Market Data of the Microsoft Co.

\begin{tabular}{|l|c|}
\hline \multicolumn{1}{|c|}{$\begin{array}{c}\text { Microsoft Co. } \\
\text { Annual Income Statement, Balance Sheet and Market Data }\end{array}$} & $\begin{array}{c}\mathbf{6 / 3 0 / 2 0 1 8} \\
\text { (values in 000's) }\end{array}$ \\
\hline Total Revenue & $\$ 110,360,000$ \\
\hline Gross Profit & $\$ 72,007,000$ \\
\hline Net Income & $\$ 16,571,000$ \\
\hline & \\
\hline Total Assets & $\$ 258,848,000$ \\
\hline Total Equity & $\$ 82,718,000$ \\
\hline & \\
\hline Market Cap & $\$ 919,997,919$ \\
\hline
\end{tabular}




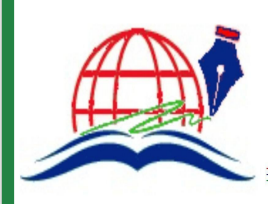

Annals of Spiru Haret University.

Economic Series

Since 2000

ISSN:2393-1795 ISSN-L:2068-6900
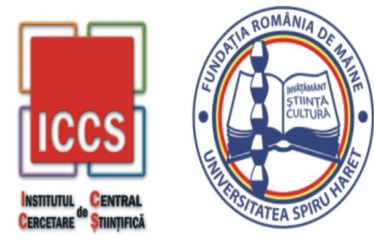

Issue 2/2019

When the latest financial statements of Microsoft Co. are examined, the data shown in Table 1 are obtained.

If Microsoft's goal was to maximize profit, it would have been necessary to double the $\$ 16.5$ billion. However, the capitalization of the Microsoft Co. firm traded on the NASDAQ exchange is approximately $\$ 920$ billion.

The market value can also be calculated according to the future expectations of the company and the discounted cash flow method. The FCFF method described above can be used in this calculation.

Market value is also used for comparison and performance measurement purposes. Valuation of a company's future expectations, current status, mergers or acquisitions is extremely important. Even the firm value can be used to compare the capital markets of countries. In our study, capital markets and total market values of selected countries are compared. For this purpose, we used information from the World Federation of Exchange.

Table 2. Country Comparison for Stock Exchange

\begin{tabular}{|l|c|c|}
\hline \multicolumn{1}{|c|}{ Country } & $\begin{array}{c}\text { Domestic market } \\
\text { capitalization (USD } \\
\text { millions) } \\
\text { (2019 January) }\end{array}$ & $\begin{array}{c}\text { Listed } \\
\text { Companies } \\
\text { (2019 January) }\end{array}$ \\
\hline Turkey - Borsa Istanbul & $\$ 167,622.5$ & 379 \\
\hline Romania - Bucharest Stock Exchange & $\$ 19,826.7$ & 85 \\
\hline & & 3,046 \\
\hline USA - Nasdaq & $\$ 10,662,317$ & 2,281 \\
\hline USA - NYSE & $\$ 22,464,237$ & 3,653 \\
\hline & & 2,209 \\
\hline Japan Exchange Group Inc. & $\$ 5,628,462.9$ & \\
\hline Korea Exchange & $\$ 1,528,824.3$ & \\
\hline & & \\
\hline London - LSE Group & $\$ 3,826,889.5$ & $\mathbf{5 2 , 2 2 3}$ \\
\hline
\end{tabular}

Source: https://www.world-exchanges.org/ 


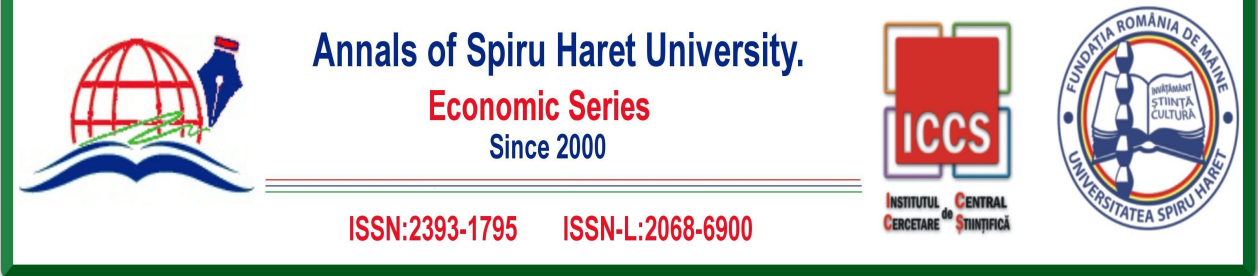

Issue 2/2019

\section{Conclusion}

Although there are many performance measures that measure company success, none is as comprehensive as value. There is a strong and linear relationship between a company's market value and its discounted cash flows. Because earnings are used to generate the income statement, they cannot be used to measure cash flows.

Firm valuation means seeking the goal of the firm which is listing it on the Stock Exchange. Real value of the firm can be calculate with different methodologies. These methods are related to future expectations or background of the firm's financial data. Discounted Cash Flow (DCF) Method is one of the firm valuation methods used all around the world and it is accepted by the experts.

If Microsoft's goal was to maximize profit, it would have been necessary to double the $\$ 16.5$ billion. However, the capitalization of the Microsoft firm traded on the NASDAQ exchange is approximately \$920 Billion.

In this study, we examined firm value concept and discounted cash flow method to determine firm value. The market value, which can also be expressed as the sum of the firm values, is also an important argument in the comparison of the capital markets of the countries. When the financial statements of Microsoft were examined, it could be determined as a purpose to increase the net profit a little if the purpose of the firm was profit maximization. However, when the market value of the same company is examined, it is seen that it has a greater value. It is also a question of how Microsoft can reach this value, which has a greater value than the Balance Sheet and Income Statement items. The continuity and anticipation of the expected future cash flows of Microsoft Co. has increased the demand of the shareholders, the shares of the company and thus the stock price of the company has increased. The increase in the share price increases the market value of the company. Therefore, the aim of the firms should be to increase the shareholder value or to take decisions to increase the stock price.

Even the market value of a firm can be more than the total market value of the countries. For this purpose, the total market value of all companies traded on the Borsa Istanbul and Bucharest stock exchanges is not even as much as Microsoft Co.

\section{References}

[1] O'Brien, T. J. (2003). "A simple and flexible DCF valuation formula." Journal of Applied Finance, 13(2). 

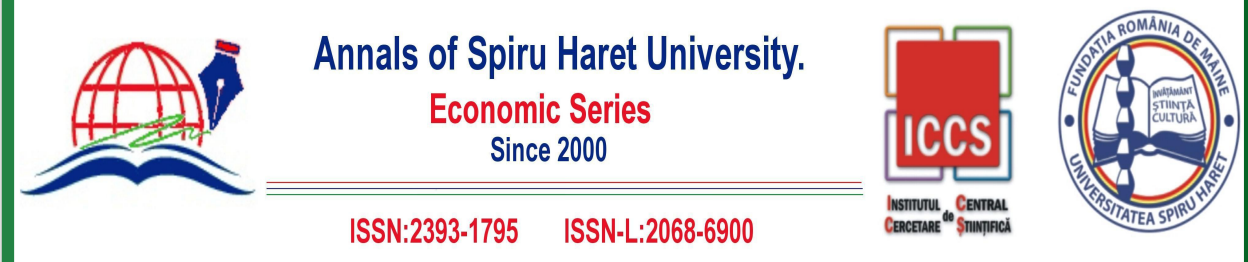

Issue 2/2019

[2] Copeland, Thomas, E., Koller, T., \& Murrin, J. (1994). "Valuation: measuring and managing the value of companies." Wiley frontiers in finance.

[3] Copeland, Thomas E., Weston, Fred J. \& Shastri, Kuldeep. Financial Theory and Corporate Policy, 4th International Edition, Pearson Publisher, 2003.

[4] Pomoni, Christina (2010), "Valuation Methods: Discounting Cash Flows vs. Relative Valuation", http://voices.yahoo.com/valuation-methods-discounting-cash-flows-vsrelative6973876.html

[5] Bal, Hasan (2011), "Özkaynağa Nakit Akımı ve Firmaya (Projeye) Nakit Akımı Yöntemlerinin Bir Projeye Yatırım Kararında Kabul ve Red Açısından Farklı Sonuç Vermelerini Etkileyen Faktörler”, İşletme Araştırmaları Dergisi, 2/1 (2010) 21-42.

[6] Aydin, Yavuz (2012), "Firma Değerleme Yöntemleri", Kırklareli Üniversitesi İ.İ.B.F. Dergisi Cilt:1, Sayı:1, Mart.

[7] Guj, Pietro (2006), "Mineral Project Evaluation - An Introduction", Philip Maxwell (der.), Australian Mineral Economics içinde, The Australian Institute Of Mining and Metallurgy, Victoria.

[8] https://www.world-exchanges.org/

[9] https://www.nasdaq.com/symbol/msft

[10] https://www.investopedia.com 
